\title{
Research on the Construction of Platform Courses of Database Principles and Applications in Information Majors
}

\author{
Yao Kang \\ Beijing City University \\ Beijing, China 100083
}

\begin{abstract}
As a specialized basic platform course for information majors, the Database Principles and Applications course also differs in the teaching needs of various majors due to the different training needs of various information majors. This paper expounds the construction and research of the platform course from many aspects such as teaching content, teaching form, team building, assessment methods, and so on. It specifically includes various teaching methods such as the division of the knowledge module in the teaching content, case teaching in the teaching method, project-driven teaching combined with national computer contests and application of flipped classroom in database comprehensive design teaching, the construction of high-quality platform course team, and the setting of reasonable assessment method.
\end{abstract}

Keywords-Database Principles and Applications; information category; platform course construction

\section{INTRODUCTION}

With the deepening of higher education reform and changes in social demand situation in China, domestic colleges and universities have adopted large category talent training mode in succession, which requires to unify the training program, build the course system, and create specialized basic platform courses based on large category. Among them, the Database Principles and Applications course is a specialized basic course for information majors, and there are differences and commonalities between different majors in the demand for students' ability training. Therefore, as a platform course research, we need to conduct a comprehensive study of the course system based on the comprehensive needs of each major.

Combined with the characteristics of the students in thirdgrade colleges and universities, this paper considers the unity of course construction in a deeper way, carries out research on many aspects in the construction of platform course, such as teaching content, teaching form, team construction, evaluation mode.

\section{THE REFINEMENT OF TEACHING CONTENT}

Different majors have different demands on students' training ability, different selection of modules, and different class hours, which leads to a certain difference in the teaching content of each major. Therefore, we need to further refine the teaching content and requirements, and deeply dig out the level difference of commonalities and requirements of each major for ability training of this course.

\section{TABLE I $\quad$ PLATFORM COURSE MOdULE DIVISION}

\begin{tabular}{|c|c|c|c|c|c|}
\hline No. & Module & Sub-module & No. & Module & Sub-module \\
\hline \multirow[t]{3}{*}{1} & \multirow[t]{3}{*}{$\begin{array}{l}\text { Foundation } \\
\text { knowledge } \\
\text { of database }\end{array}$} & $\begin{array}{l}\text { Basic } \\
\text { concept of } \\
\text { database } \quad(1- \\
\text { 1) }\end{array}$ & 4 & $\begin{array}{l}\text { Theoretica } \\
1 \text { basis of } \\
\text { relational } \\
\text { database }\end{array}$ & $\begin{array}{l}\text { Normalization } \\
(3-1)\end{array}$ \\
\hline & & $\begin{array}{ll}\text { Data } & \text { model } \\
(1-2) & \end{array}$ & \multirow[t]{2}{*}{5} & \multirow[t]{2}{*}{$\begin{array}{l}\text { Database } \\
\text { maintenan } \\
\text { ce } \\
\text { manageme } \\
\text { nt }\end{array}$} & $\begin{array}{l}\text { Basic concept } \\
\text { of database } \\
\text { security } \\
\text { operation (5- } \\
\text { 1) }\end{array}$ \\
\hline & & $\begin{array}{l}\text { Three-tier } \\
\text { mode of } \\
\text { database (1- } \\
\text { 3) }\end{array}$ & & & $\begin{array}{l}\text { Database } \\
\text { security } \\
\text { management } \\
(5-2)\end{array}$ \\
\hline \multirow[t]{4}{*}{2} & \multirow[t]{4}{*}{$\begin{array}{l}\text { Basic } \\
\text { concept of } \\
\text { relational } \\
\text { database }\end{array}$} & $\begin{array}{l}\text { Relation } \\
\text { model (2-1) }\end{array}$ & \multirow[t]{2}{*}{6} & \multirow[t]{2}{*}{$\begin{array}{l}\text { Database } \\
\text { programm } \\
\text { ing }\end{array}$} & $\begin{array}{l}\text { T-SQL } \\
\text { programming } \\
\text { foundation (6- } \\
\text { 1) }\end{array}$ \\
\hline & & $\begin{array}{l}\text { Relation } \\
\text { operation (2- } \\
\text { 2) }\end{array}$ & & & $\begin{array}{l}\text { Stored } \\
\text { procedure and } \\
\text { trigger } \\
\text { programming } \\
(6-2)\end{array}$ \\
\hline & & $\begin{array}{l}\text { Relation } \\
\text { integrity } \\
\text { constrain (2- } \\
\text { 3) }\end{array}$ & \multirow[t]{5}{*}{7} & \multirow[t]{5}{*}{$\begin{array}{l}\text { Database } \\
\text { design }\end{array}$} & $\begin{array}{l}\text { Basic methods } \\
\text { and } \\
\text { procedures of } \\
\text { database } \\
\text { design (7-1) }\end{array}$ \\
\hline & & $\begin{array}{l}\text { Relation } \\
\text { algebra (2-4) }\end{array}$ & & & $\begin{array}{l}\text { Demand } \\
\text { analysis (7-2) }\end{array}$ \\
\hline \multirow[t]{4}{*}{3} & \multirow{4}{*}{$\begin{array}{l}\text { Basic } \\
\text { operation } \\
\text { and } \\
\text { managemen } \\
t \text { of } \\
\text { database }\end{array}$} & $\begin{array}{l}\text { SQL } \\
\text { overview (4- } \\
\text { 1) }\end{array}$ & & & $\begin{array}{l}\text { Conceptual } \\
\text { structure } \\
\text { design (7-3) }\end{array}$ \\
\hline & & $\begin{array}{ll}\text { Data } & \text { query } \\
(4-2) & \end{array}$ & & & $\begin{array}{l}\text { Logical } \\
\text { structure } \\
\text { design (7-4) }\end{array}$ \\
\hline & & $\begin{array}{l}\text { Data } \\
\text { updating (4- } \\
\text { 3) }\end{array}$ & & & $\begin{array}{l}\text { Physical } \\
\text { design of } \\
\text { database (7-5) }\end{array}$ \\
\hline & & $\begin{array}{l}\text { Definition of } \\
\text { database } \\
\text { object (4-4) }\end{array}$ & & & \\
\hline
\end{tabular}


We fully consider the teaching content and the required training ability of Database Principles and Applications in five majors, and carry out module division for platform courses, including 6 large modules and 17 sub-modules. Each large module has an overall course objective for the module, and the corresponding standard for each performance is set for the performance of each sub-module. Various information majors can select modules based on their major requirements. For example, majors of electronic information engineering, communication engineering, and Internet of things engineering have high requirements for data storage and operation, so submodule learning can be selectively reduced in design and basic theory. Majors of software engineering, computer science and technology, and information management and information system require high comprehensive design and development of the database, so all modules are selected and use performance evaluation criteria. The program of each module is designed from the aspects of cases, teaching requirements, assessment content, assessment methods and classroom design. Seeing "Table I" for details.

\section{TEACHING METHOD DESIGN}

\section{A. Implementing Case Teaching}

With very strong theoretical property and practicalness, database principle and application course faces practical application. The course adopts case study by through, and all the teaching content can be carried out based on the students course selection management system. From database design to database application and operation to database development, the management system can better systematize knowledge point. However, the experiment of this course is based on the operation from database design to database implementation by taking a book borrow management system as an example, and runs through the whole database principle and application knowledge hierarchy.

\section{B. Flipped Classroom to Conduct Project Driving Teaching}

Combined with Pocket Parking System (Computer Design Contest Project for University Students in China in 2017), a practical case of application development project, this course adopts the teaching method of flipped classroom and runs through the whole process of database design: process analysis for system operation ->drawing of E_R diagram in system $>$ distinction of foreground-background function demand >information data extraction analysis->logic framework design of database -> database realization, so as to make students have the ability to design complex project databases.

Specific implementation processes of flipped classroom are as follows:

- Assign project to the students before class. Students are divided into groups after class to carry out relational database design according to the demands of project;

- Select a group of works to carry out report before class according to the works submitted by students;
- Teacher analyzes the student's work before class, summarizes the problems most students have, and classifies the problems;

- In class, after students finish the report, combined with the arising problems (and the classified questions by teacher before class), teacher organizes group discussion and gives the solutions;

- After discussion, teacher summarizes the arising problems in the students' design and solutions.

Through this kind of form, students have clear design ideas, specific methods and more reasonable design for the database project with complex requirements.

Because the flipped classroom is an experiment during this semester, it is just applied to my class and not requires all the teachers in the group of platform courses to apply. Through the attempt in this semester and after discussion and conclusion of teaching team after class, it will be popularized in the future teaching.

\section{Project-driven Experiment and Practice Teaching}

In the implementation process, Database Principles and Applications platform courses pay attention to practical teaching, put emphasis on training the engineering application ability and innovation ability of the students. The course integrates the actual project that teacher participates in into the classroom teaching. However, the classroom teaching adopts book borrow management system of a synthesis example that runs through the whole curriculum knowledge system as the experimental context, and the experiment link mainly includes replication experiment, applicable experiment and comprehensive experiment. This will further consolidate students' understanding of knowledge points and improve students' engineering application ability.

\section{Independent Study Management after Class}

To enhance the management for student's independent study after class, compile the exercise book of course and require students to finish the reviewing of knowledge points after class.

\section{E. Integrated Teaching Form}

This project plans to construct diversified teaching platform. The Database Principles and Applications course requires submitting much homework in document form. Therefore, to construct web-based teaching platform of universities, provide convenience for students and teachers in platform course and make students use phones to study after class, this project plans to use WeChat official account of micro-teaching assistant to create routine teaching platform on mobile terminal and constructs multilevel and multidimensional teaching mode of online and offline integration. 


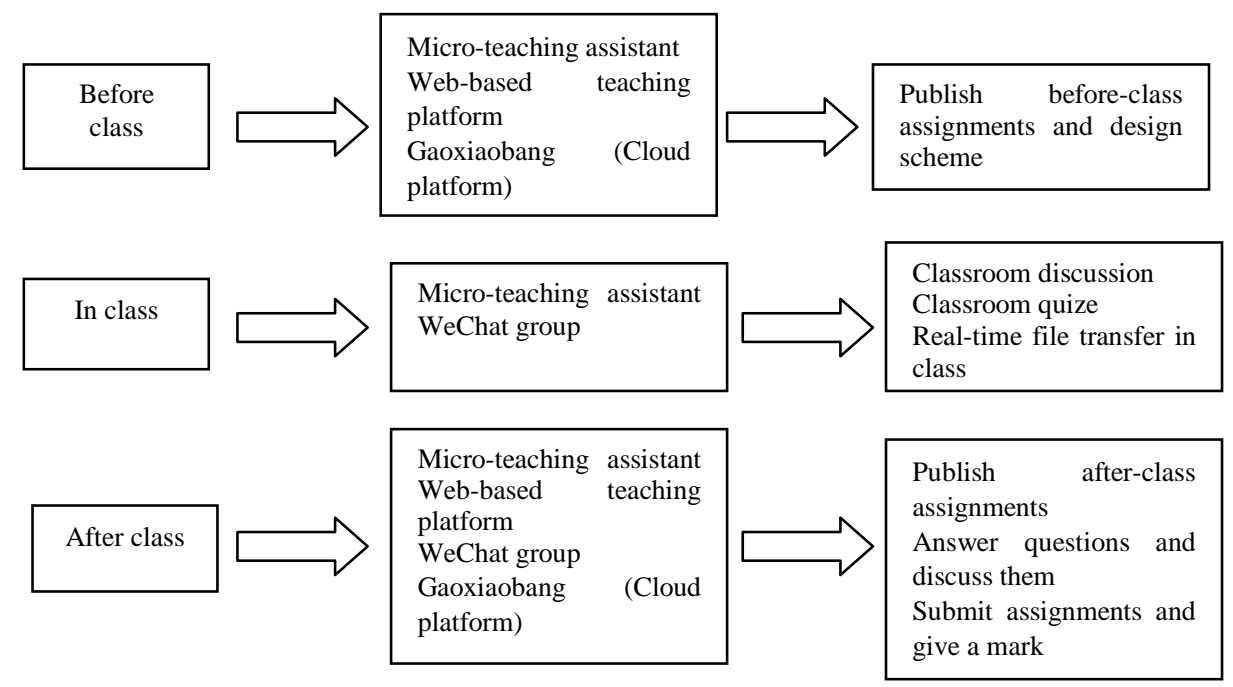

Fig. 1. Teaching mode of online and offline integration.

\section{StRengthening The Role of Teaching Team In THE CONSTRUCTION OF PLATFORM COURSES}

The professional teaching team comprehensively analyzes the demands of ability training of each major, through group discussion and expert argumentation, teases out the knowledge module and training objectives of the course, analyzes the application of all the knowledge in the training of professional ability, and then enhances the reuse of this course in the specialized course system. After synthesizing the unified course outline, we need to further study the differential application of all the knowledge in majors. For example, in project-driven teaching, team teachers will choose projects with professional characteristics to strengthen knowledge training, so that students have a stronger understanding of the course and a clearer purpose in course learning.

Building a stable platform course faculty is conducive to the construction of the platform course. The faculty structure is reasonable, and all teachers can undertake both theoretical and practical teaching. Platform course teachers should listen to each other, learn from each other, complement each other, and supply each other's needs. The platform course group meetings are held regularly to communicate and exchange problems in the platform class teaching, and promote the common improvement of teaching level.

\section{IMPROVING THE STUDENTS' ENGINEERING PRACTICE ABILITY}

As a part of the design of the application program, the design requirement of database must be based on the actual software project requirements. Course teaching cases and experimental guidance training cases are mainly set for learning the teaching knowledge, and its functional requirements are relatively simple. If we want to improve the engineering practice ability of students' database design operations, we must combine the actual project, and the competition projects are mostly real projects of enterprises, and their needs are relatively complicated. Therefore, a characteristic link in the construction of this topic platform is to combine the software design problems of Computer Design Contest for University Students in China every year to design the stage assessment of the course and to improve the students' engineering practice ability. In addition, we summarize the competition topics over the years, and write a database design project set.

\section{A. The Combination of Integrated Course Design and Competition Topic Selection}

The comprehensive design ability of the course is assessed in the process assessment of the Database Principles and Applications course. The topic is combined with the subject of National Computer Design Competition, this project will design the systematic database according to the requirement description of subject in the competition, assess database design, database realization and operation, expand the topic to the courses of system development design in the next semester, integrate the competition project into the development course group of integrated information major system development, run through the actual project into all the courses of this course group, so as to enhance the professional and comprehensive engineering practice ability of the students.

\section{B. Introducing Contests in Flipped Classrooms}

The teacher takes a certain subject in the computer design competition as the content of the comprehensive design and analysis of the database. Starting from a practical project with complex requirements, the teacher systematically carries on training of the whole process of database design, takes the way of flipped classrooms, divides the students into groups and enhances the actual engineering practice ability of the students.

\section{STUDY ON THE ASSESSMENT FORM AND CONTENT}

Database Principles and Applications is a specialized basic course, which not only emphasizes the practical ability, but also stresses the proficiency in the knowledge of the course. Therefore, we must pay attention to the comprehensive 
assessment of practical operation and foundation stability in the assessment methods. There are two types of assessment methods, that is, skill test and written test.

The assessment design of skill test is to prepare database system design and implementation report, and the written test assesses the basic principles of the database principle and operation, and the ability to use the sentence. According to the different design of the course teaching progress, the written teat will be applied in the stage assessment and the final assessment.

\section{CONCLUSION}

The Database Principles and Applications course is a specialized basic platform course for information majors, and it cultivate students around the two core competencies of relational database design and database SQL language. This paper studies the construction of the platform in various aspects such as teaching content, teaching form, team building and assessment methods, and lays a solid knowledge foundation for the subsequent system development courses.

\section{REFERENCES}

[1] Shen Hua. Application of Flipped Classroom in Project-driven Teaching - Taking the Teaching of Database Principles and Applications as An Example [J]. Computer CD Software and Applications, 2014, 17 (17): 197-199. 申华.翻转课堂在项目驱动式教学中的应用一以《数据库 原理与应用》教学为例 [J]. 计算机光盘软件与应用,2014,17(17):197199.

[2] Fu Yunfang. Discussion on Experimental Teaching Mode of Database Principle and Application [J]. Experimental Technology and Management, 2011, 28 (08): 291-293. 符蕴芳.“数据库原理与应用”实 验教学模式探索[J].实验技术与管理,2011,28(08):291-293.

[3] Ye Xia, Li Junshan, Li Hailong. Innovation of Practice Teaching on Database Principle and Application [J]. Computer Education, 2011 (01): 56-59. 叶霞,李俊山,李海龙. 数据库原理及应用实践教学改革 $[\mathrm{J}]$.计算 机教育,2011(01):56-59.

[4] Jiang Guiying, Sun Jie, Lv Xin. Construction of Platform Course in Main Category of Information Technology and Its Application[J]. Education and Teaching Forum, 2013(09):185-186. 蒋桂英,孙杰,吕新. 《信息技术及其应用》大类平台课程的建设 [J].教育教学论 坛,2013(09):185-186.

[5] Xu Fengsheng. Construction and Practice of Curriculum Group for Basic Platform Course in Information and Computing Science - Taking Dezhou University as An Example [J]. China University Teaching, 2013 (01): 57-59. 徐风生.信息与计算科学专业基础平台课课程群的 建设与实践——德州学院为例 [J].中国大学教学,2013(01):57-59. 